\title{
Performance of potato varieties under the climatic conditions of Abbottabad Hazara
}

\author{
Rafeh Ullah ${ }^{1}$, Ghulam Nabi ${ }^{1}$, Nangial Khan ${ }^{2 *}$, Abdullah Khan ${ }^{1}$, Bilal \\ Ahmad Khan ${ }^{3}$, Rafi Ullah ${ }^{1}$, Imtiaz Khan ${ }^{1}$ and Jawad Ali Jan ${ }^{1}$ \\ 1. Department of Horticulture, The University of Agriculture, Peshawar-Pakistan \\ 2. State Key Laboratory of Cotton Biology, Institute of Cotton Research, Chinese Academy of Agricultural Sciences, \\ Anyang, Henan-China \\ 3. Hazara Agriculture Research Station, Abbottaad-Pakistan \\ *Corresponding author's email: nangialkhan@aup.edu.pk
}

Citation

Rafeh Ullah, Ghulam Nabi, Nangial Khan, Abdullah Khan, Bilal Ahmad Khan, Rafi Ullah, Imtiaz Khan and Jawad Ali Jan. Performance of potato varieties under the climatic conditions of Abbottabad Hazara. Pure and Applied Biology. Vol. 8, Issue 2, pp1744-1756. http://dx.doi.org/10.19045/bspab.2019.80118

\begin{tabular}{llll}
\hline \hline Received: 16/02/2019 & Revised: 17/06/2019 & Accepted: 24/06/2019 & Online First: 29/06/2019 \\
\hline \hline
\end{tabular}

\section{Abstract}

An experiment "Performance of potato varieties under the agro-climatic conditions of Abbottabad Hazara" was conducted in Spring, 2016 at the Hazara Agriculture Research Station Abbottabad. The experiment was laid out in Randomized Complete Block Design. Total treatments were consisted of ten varieties i.e. Rock, Red Sum, Aurea, Nazca, Focus, Eldorado, Desiree, Elbeida, Red Valentine and Toureg and all treatments were replicated three times. Sprouting percentage was found maximum in Red Valentine (98.3), followed by Red Sum (97.5), Eldorado (95.8) and Aurea (92.5). The maximum number of stem plant ${ }^{-1}$ was noted in Red Sum (5), followed by Rock (5), Focus (5), Nazca, Eldorado and Red Valentine (4 number in each). Red Sum and Red Valentine got least disease and less number of small tubers. The highest number of medium size tubers plot $^{-1}$ were recorded in Red Valentine (39), followed by Red Sum (35). Red Sum and Red Valentine produced highest number of large size tubers plot $^{-1}(27$ and 25). Eldorado had maximum total number of tubers plot $^{-1}(170)$. The smallest weight of small tuber plot $^{-1}$ was noted in variety Red Valentine $(2.2 \mathrm{~kg}$ ), followed by Red Sum and Focus with 2.3 and $2.8 \mathrm{~kg}$ respectively. While maximum weight of medium tubers plot $^{-1}$ and maximum total weight of tubers plot ${ }^{-}$ ${ }^{1}$ was recorded in variety Red Valentine $(8.2$ and $18.8 \mathrm{~kg}$ ), followed by Red Sum7 and $18.7 \mathrm{~kg}$ respectively. The highest weight of large tubers plot $^{-1}$ was recorded in Red Sum $(9.4 \mathrm{~kg})$ and the least moisture was recorded in variety Red $\operatorname{Sum}(73.7 \%)$, followed by Red Valentine (74.3\%) and Toureg (77.7\%), while highest dry matter was recorded in variety Red Sum(26.3\%), followed by Red Valentine (25.7\%) and Toureg. The maximum yield (ton/ha) was recorded in Red Valentine (25), followed by Red Sum (24.9). It is concluded that variety Red Sum and Red Valentine showed superior results in the agroclimatic conditions of Abbottabad Hazara.

Keywords: Climatic condition; Growth; Hazara; Potato; Varieties and Yield

\section{Introduction}

Potato (Solanum tuberosum L.) is a most important vegetable and the main cash crop of farmers, especially in hilly areas of Pakistan. Potato originated in South America of Andes mountain ranges at elevations up to 15,000 feet in Peru,
Columbia, Ecuador and Bolivia. Currently there are more than 2,000-3,000 varieties extant today and potatoes have been in cultivation for more than 2000 years. It is herbaceous perennial in its native habitation, however treated as a tender annual in the temperate regions. Potato damaged $28^{\circ}-30^{\circ}$ 
F by frost. Potato being 4th important crop of the world. It is a good food and a good source of carbohydrates, vitamins, minerals and proteins. The moisture contents is about $80 \%$ in the bulk and the remaining $20 \%$ dry matter contains $17 \%$ carbohydrates and $2 \%$ proteins while rest is composed of fiber, minerals, vitamins and fats [1].

Pakistan has favorable agro-climatic conditions for producing four crops of potato round the year in different places of the country like autumn in plains of Punjab and Khyber Pakhtunkhwa, winter in southern Punjab, Sind and plains of Baluchistan, whereas spring crops in plains and lower hills of Punjab and Khyber Pakhtunkhwa and summer crops in high hills of Baluchistan, Khyber Pakhtunkhwa, Punjab and Azad Jammu and Kashmir (AJK) [2].

In Pakistan, Punjab is a leading potato producer which contributes $80 \%$ in area and more than three quarters $(75 \%)$ of total production in Pakistan. In Khyber Pakhtunkhwa the situation are congenial for raising three crops of potato round the year i.e. autumn, spring and summer. The total production of potato in Pakistan in 2000-01 was about 1.66 million tonsthat increased in 2009-10 to 3.14 million tons. The production of potato further increased in 2010-11 from 3.49 million tons to 3.55 million tons in 2011-12, which was the maximum in the history of potato production in the country. In Khyber Pakhtunkhwa the area of potato crop in 2015-2016 was 9367 ha and the production was129501 tons [3]. In 2016-17 the total production area of potato in Pakistan was 179.6 ha and the production was 3852.9tons, while in 201718 the total production area was 187.2 ha and the production was 3853.9 tons [4].

Abbottabad is subtropical area having humid types condition ranging from mild to warm temperature, hot temperatures during June and July while cool to mild temperatures during the wintertime. During mid-summer the temperature rises as high as $38{ }^{\circ} \mathrm{C}$ but during the extreme cold waves it drop below $-5{ }^{\circ} \mathrm{C}$. The average annual rainfall is 1262 $\mathrm{mm}$. The snowfall occurs rarely in December and January. In general, heavy rainfall events occurs during the monsoon season which is from July to September that frequently cause flooding in lower lying parts of the city (Wikipedia).

The evaluation of new cultivars for the value addition products is essential developed for high yield, disease and insect resistance, harvesting and handling efficiencies, or even storability however, if unacceptable products are manufactured from these new cultivars, they are of little value to either the producer or the processor. Research workers in several parts of the world evaluated new cultivars showing market potential and quality potato products. The method of planting, plot size, row length and spacing, seed piece spacing, and fertilizer rates should be controlled for each cultivar. A record should also be made of planting dates, vine killing dates if used, daily mean temperatures, rainfall, and harvesting dates. Ideally the cultural practices for each trial should be similar to those used by commercial growers in the test area [5].

There are numbers of good potato cultivars available but the cultivation of old cultivars continuously loose quality and become susceptible to insect, pest and disease. Therefore this experiment was designed to check the performance of potato varieties under the agro-climatic conditions of Abbottabad Hazara.

\section{Materials and methods}

An experiment "Performance of potato varieties under the agro-climatic conditions of Abbottabad Hazara" was conducted in spring, 2016 at the Hazara Agriculture Research Station (HARS). The experiment was laid out in Randomized Complete Block Design. Total treatments (varieties) were ten 
i.e. Rock, Red Sum, Aurea, Nazca, Focus, Eldorado, Desiree, Elbeida, Red Valentine and Toureg and all treatments were replicated three times. The tubers of desired varieties were collected from HARS and were sown on January and were harvested in May, in a well prepared field/plot. The rate of recommended fertilizer was applied 200150-75 NPK kg/ha [6]. First irrigation was practiced immediately after planting. All subsequent irrigations were applied at intervals 10-12 days depending upon climatic conditions. Row to Row distance was $75 \mathrm{~cm}$ and Tuber to Tuber distance was
$25 \mathrm{~cm}$ [7]. Total Tubers per plot were 40 numbers. Total area per plot was $5 \times 1.5 \mathrm{~m}$ $\left(7.5 \mathrm{~m}^{2}\right)$ and the total experimental plot area was $7.5 \times 30\left(225 \mathrm{~m}^{2}\right)$. All cultural practices and crop protection measures were adopted according to the need.

Data were recorded on the following parameters

Sprouting (\%)

The number of seedlings which was survived after transplanting was counted in each plot and the percentages were calculated by the following formula.

Sprouting percentage of tubers $=\underline{\text { Number of sprouted tubers } \times 100}$

Total Number of tubers

Number of stems plant ${ }^{-1}$

The number of stems was recorded randomly with five selected plants at three different places in every plot and after that means were estimated.

Disease percentage $=$ Number of affected plants $\times 100$ Total Number of plants

Number of small Tubers plot ${ }^{-1}$ (less than 20mm)

Number of small tubers plot ${ }^{-1}=$ No. of small tubers per treatment $\times 7.5 \mathrm{~m}^{2}$

Total area of the treatment (sq. meter)

Number of medium tubers plot $^{-1}(20$ -

$50 \mathrm{~mm})$

The number of medium tubers per plot (20-

$50 \mathrm{~mm})[8]$ was counted and the mean were calculated by following formula.

No. of medium tubers plot ${ }^{-1}=\underline{\text { No. of medium tubers per treatment } \times 7.5 \mathrm{~m}^{2}}$

Total area of the treatment (sq. meter)

Number of large Tubers plot $^{-1}$ (more than $50 \mathrm{~mm})$

Number of large tubers plot ${ }^{-1}=$ No. of large tubers per treatment. $\times 7.5 \mathrm{~m}^{2}$

The number of large tubers per plot (more than $50 \mathrm{~mm}$ ) [8] was counted and the mean were calculated by following formula.

\section{Total Number of Tubers plot ${ }^{-1}$}

The recorded data was used by counting the total number of tubers plot $^{-1}$ and the mean were calculated.

Weight of small tubers plot ${ }^{-1}=\underline{\text { Weight of small tubers per treatment } \times 7.5 \mathrm{~m}^{2}}$
Weight of small Tubers plot $^{-1}($ less than 20mm)

The weight of small tubers plot $^{-1}$ (less than $20 \mathrm{~mm}$ ) was weighted in kilogram and the mean were calculated by following formula.

Total area of the treatment (sq. meter) 
Weight of medium Tubers plot $^{-1}(20$ 50mm)
The weight of medium tubers plot $^{-1}(20-$ $50 \mathrm{~mm}$ ) was weighted in kilogram and the mean were calculated by following formula.

Weight of medium tubers plot ${ }^{-1}=$ Weight of medium tubers per treat $\times 7.5 \mathrm{~m}^{2}$

Total area of the treatment (sq. meter)

Weight of large Tubers plot $^{-1}$ (more than 50mm)
The weight of large tubers plot $^{-1}$ (more than $50 \mathrm{~mm}$ ) was weighted in kilogram and the mean were calculated by following formula.

Weight of large tubers plot ${ }^{-1}=\underline{\text { Weight of large tubers per treatment } \times 7.5 \mathrm{~m}^{2}}$ Total area of the treatment (sq. meter)

Total Weight of Tubers $\operatorname{plot}^{-1}(\mathbf{k g})$

Total weight of tubers in every plot of small, medium and large was weighted and express in $\mathrm{kg}$.

Moisture (\%)

A cover glass dish was heated to $130^{\circ} \mathrm{C}$ for drying and then allowed to cool 10 grams slices and carefully weighed in the dish and Moisture content $\%=$ Loss of sample weight $\times 100$

\section{Dry Matter (\%)}

Fresh Weight of sample

The dry matter percentage was measured after removing the slice from oven by Dry weight $(\%)=$ Dried weight of sample $\times 100$ Yield hectare ${ }^{-1}$ (tons) Fresh weight of sample

Yield in tons ha ${ }^{-1}=$ Yield per plot in $(\mathrm{kg}) \times 10,000 \mathrm{~m}^{2}$

Statistical Procedure Area of plot $\left(\mathrm{m}^{2}\right) \times 1000$

All the data were subjected to statistical analysis by using Stastics Software 8.1. Significant differences in means were separated by using LSD test.

\section{Results and discussion}

\section{Sprouting (\%)}

The data for sprouting percentage are given in (Table 1). The sprouting percentage was significantly affected. The maximum sprouting was recorded in variety Red Valentine (98.3\%), followed by Red Sum $(97.5 \%)$ Eldorado (95.8\%) and Aurea $(92.5 \%)$, while the minimum sprouting was recorded in variety Toureg (66.7\%) and Focus $(71.7 \%)$. On the other hand Red Valentine and Red Sum produced significantly higher sprouting percentage, place in oven. The oven were heated to $130^{\circ} \mathrm{C}$ and then remain at this temperature for one hour. After one hour the dish was removed and transferred to dissicator. The sample was weighed again as soon as it reached to the room temperature. The percentage was calculated by following formula:

multiplying dried weight of sample with 100 and divide by fresh weight of the sample with following formula.

Yield hectare ${ }^{-1}$ (tons) was calculated by using following formula:

whereas the Toureg and Focus produced minimum sprouting percentage.

The higher sprouting percentage of Red Valentine and Red Sum is due to good source, good quality, and pre-sprouted tubers and mature at the time of planting and also better adaptation of variety to the environmental condition of Abbottabad Hazara. While the poor emergence percentage was recorded for the variety Toureg. This is the genetic character of the variety [9].The emergence relies mainly on the use of utilization of reserve and metabolites in maternal tubers [10].

Number of stems plant ${ }^{-1}$

The maximum number of stem plant ${ }^{-1}$ was noted in Red Sum (5.3), followed by Rock (5), Focus (5), Nazca, Eldorado and Red 
Valentine (4.6 number in each). The statistical analysis of data revealed that the maximum number of stem per plant was produced by variety Red Sum after the completion of sprouting followed by Rock and Focus, while Desiree and Elbeida produced minimum number of stems per plant (3.6).

The difference in number of stems per plant of all these varieties due to genetic character and their adaptability to different soil climatic conditions which give more number of stems per plant. It is also because of good sprouting percentage.

$[11,12]$ in their study showed that between the varieties in eyes of the number of mainstem, there are significant differences. The other results reported that the number of stem per plant stronglydepends on the number of tubers per plant [13]. The minimum number of stem $^{-1}$ may be due to compact soil, causes no aeration and lack of porous soil. The results of [14] who described that TPS families produced mostly higher number of stems and better growth them that of standard varieties. The [15] matched two different ages of seed tubers young and old, indicating that young seed grew slowly, produced fewer stems, while older seeds grow faster and produced more stems. The number of stems per plant is an important parameter because it is directly related to the production of tubers and is important for tuber grading. Less number of main stems had tubers of large size (Table 1).

\section{Disease (\%)}

The potato crops were affected by late blight (Phytopthora infestens) which destroys the leaves, stems, fruits and tubers of potato. The maximum disease affected variety was Focus (42.5\%) and Aurea (38.3\%), followed by Eldorado and Elbeida (33\%), while the minimum disease affected variety was Red Sum (5\%) and Red Valentine (6.7\%). On the other hand Focus and Aurea significantly maximum disease affected, whereas the Red Sum and Red Valentine got least disease affected.

Focus and Aurea was maximum affected followed by Eldorado and Elbeida. It is due to susceptibility of a variety to disease. It is reported that susceptibility of the plant may be due to the high relative humidity of the area [16]. Whereas Red Sum and Red Valentine affected the minimum disease percentage. It may be due to genetic characteristics and resistance to disease. Some varieties which is high resistant to disease and some varieties has very susceptible. Mostly crop which are vegetative propagated like potato can be an essential source of disease inoculation. Some types of damage that may affect plant vigor and subsequent production also occur on the seed tuber of the potato crop. The production problems can control which depends on the identification of diseased or defective seed tubers (Table 1).

\section{Number of small tubers plot $^{-1}$ (less than 20mm)}

The number of small tubers plot $^{-1}$ was significantly affected. The highest quantity of small tubers per plot was recorded in variety Eldorado (131), followed by Toureg (125), followed by Nazca (116) and Desiree (110) after harvesting, while the variety Red Sum had less number of small tubers plot $^{-1}$ (57), followed by Red Valentine (64). The number of small tubers per plot were significantly affected, all the ten varieties planted, Eldorado gave better result followed by Toureg, while the lowest number of small tubers per plot was given by Red sum and Red Valentine.

The variety Eldorado gave better result followed by Toureg and Nazca. It is due to because of compact soil, may be due to genetic character of a variety, because potato has mostly weak shallow root system and cannot fight with weeds and all the nitrogen and nutrients over there used by 
weeds as a result small size tubers will be obtained. It also may due to source of tubers, because improved tubers quality produced healthy plants with more marketable size tubers as compared to poor quality tubers. The lowest number of small tubers per plot was given by Red sum followed by Red Valentine. This is due to the genetic character of a variety and also environmental condition of the region.

In other research it is reported that the fraction of the smallest grade of autumn and spring seedlings crop were 36.30 and $40.70 \%$, respectively [17]. [18, 19] reported that higher number of tubers as well as varietal character, adaptability or establishment is the reason to effects the yield of small tubers of the other growth attributes. [20, 21] noted that crop had more number of stems produced smaller potato tuber size.

\section{Number of medium tubers plot $^{-1}$ 50mm)}

The number of medium tubers plot $^{-1}$ was significantly affected. The maximum number of medium size tubersplot ${ }^{-1}$ was recorded in Red valentine (39), followed by Red Sum (35), while the minimum number of medium tubers plot ${ }^{-1}$ was found in variety Toureg and Rock (23 and 25).On the other hand Red Valentine and Red Sum produced significantly higher number of medium size tubers plot ${ }^{-1}$ out of ten varieties, whereas the Toureg and Rock produced minimum number of medium size tubers plot $^{-1}$.

The variety Red Valentine produced significantly higher number of medium size tubers plot ${ }^{-1}$ followed by Red Sum. It is due to a varietal character. It may also be due to good environmental condition and source of tubers because improved quality of tubers produced healthy plants with more marketable size tubers. Whereas the Toureg and Rock produced minimum number of medium size tubers plot $^{-1}$. It is mostly due to varietal character which gave more number of large size tubers and ultimately there was less number of medium and small size tubers. [18, 22] defined that rapid appearance and superior plant growth results in higher number of medium size tubers.

\section{Number of large tubers plot $^{-1}$ (more than $50 \mathrm{~mm}$ )}

The number of large tubers plot $^{-1}$ was significantly affected. The variety Red Sum produced highest number of large size tubers plot $^{-1}$ (27), followed by Red Valentine, Focus, Aurea and Elbeida with 25, 18, 17 and 16 tubers per plot, respectively, whereas the minimum number of large tubers per plot $^{-1}$ was found in variety Toureg (11) and Eldorado (14). On the other hand Red sum produced significantly higher number of large size tubers plot $^{-1}$ followed by Red Valentine, whereas the variety Toureg and Eldorado produced minimum number of large size tubers plot $^{-1}$.

The variety Red sum produced significantly higher number of large size tubers plot $^{-1}$ followed by Red Valentine. It may due to genetic character of a variety, good environmental condition of the region and more aeration. It may also depend on the good tuber variety. If the variety belongs to good quality, then it will produced healthy plants with more large size tubers. Whereas the variety Toureg and Eldorado produced minimum number of large size tubers per plot. This is due to more compact soil. It is also due to the lack of porous soil and low nitrogen and nutrients used by weeds. It may be due to poor quality of tuber, which showed poor growth and large number of small size tubers [2]. A plant which produced from large and very big seed formed smaller but many tubers, however those established from small to medium sized seed produced few but large tubers as previously described [10, 23].

\section{Total number of tubers plot $^{-1}$}

The total number of tubers plot $^{-1}$ were significantly affected. The maximum total 
number of tubers plot $^{-1}$ was recorded in variety Eldorado (170) followed by Nazca (162) and Toureg (160) after harvesting, however the minimum total number of tubers plot $^{-1}$ was found in variety Red sum (120) and Red Valentine (128).On the other hand Eldorado produced significantly higher total number of tubers plot $^{-1}$ followed by Nazca, whereas the Red sum and Red Valentine produced minimum total number of tubers plot $^{-1}$.

The variety Eldorado produced significantly higher total number of tubers plot $^{-1}$ followed by Nazca. It is due to good emergence percentage, good environmental condition and also due to genetic character of a variety. It is also good spread of plant, because the good spread plant more area was visible to sunlight which enlarged photosynthesis and thus increase starch gathering and directed to increase yield. The more number of stem per plant also increased yield. Whereas the variety Red sum and Red Valentine produced minimum number of large size tubers plot ${ }^{-1}$. It may be due to the genetic character of a variety, compact soil because the crop could not attained porous soil and nitrogen, if there are some nutrients, it is used by weeds. The study of $[24,25]$ also stated that potato crop growing by TPS families was more economical. [11] Conducted two year experiment on two varieties Maris Piper and Desiree that found there were different in each plant between the numbers of tubers per plant.

[26] examined a number of years on record variety in some areas, and they found increasing in stem, caused increased in tubers. [27] stated that number of tubers per plant is increased with late harvesting. [28] Indicated that number of stems plot $^{-1}$ is important for number of tubers plot ${ }^{-1}$, total number of stolons and stolons tuberized.

\section{Weight of small tubers plot $^{-1}$ (less than 20mm)}

The weight of small tubers plot $^{-1}$ was affected significantly. The maximum weight of small tubers plot ${ }^{-1}$ was noted in Elbeida $(4.1 \mathrm{~kg})$ after harvesting and then weighted, followed by Eldorado $(4 \mathrm{~kg})$ and Toureg $(3.6 \mathrm{~kg})$, while the minimum weight of small tubers plot $^{-1}$ was found in variety Red Valentine $(2.2 \mathrm{~kg})$ and Red Sum (2.3 $\mathrm{kg})$.The weight of small tuber plot $^{-1}$ has significant effect. On the other hand Elbeida produced significantly higher weight of small tubers plot ${ }^{-1}$ followed by Eldorado, whereas the Red Valentine and Red sum produced minimum weight of small size tubers plot $^{-1}$.

Maximum weight of small tubers plot $^{-1}$ was recorded by Elbeida followed by Eldorado and Toureg. It may be due to the character of a variety which produced high number of small tubers and low number of medium and large tubers, while the minimum weight of small tubers plot $^{-1}$ was recorded by Red Valentine and Red Sum, it may be due to genetic character of a variety which produced more number of medium and large size tubers and least number of small size tubers. [29] Stated that the result of inheritance was significant with respect to the grades of tuber. The necessary reasons that affect the percentage of different tuber sizes are vegetative growth and stem numbers that influence varieties differentially [30]. The result for unmarketable potato varieties yield in the present work is in link with the conclusions of [31], who described that the contact effects of growing environment and genotype significantly influence unmarketable tuber yield.

\section{Weight of medium Tubers plot ${ }^{-1}$ (20- 50mm)}

The weight of small tubers plot $^{-1}$ was significantly affected. The Maximum weight of medium tubers plot $^{-1}$ in $\mathrm{kg}$ was recorded 
in variety Red Valentine $(8.2 \mathrm{~kg})$, followed by Red Sum $(7 \mathrm{~kg})$ and Nazca $(5.5 \mathrm{~kg}$ ), while the minimum weight of medium tubersplot ${ }^{-1}$ was found in variety Toureg (4 $\mathrm{kg}$ ) and Focus (4.1).The weight of medium tubers per plot has significant effect. On the other hand Red Valentine produced significantly higher weight of medium tubers plot ${ }^{-1}$ followed by Red Sum, whereas the variety Toureg and Focus produced minimum weight of medium size tubers plot $^{-}$ 1 .

The Maximum weight of medium tuber plot $^{-}$

1 was recorded by Red Valentine followed by Red Sum and Nazca. It was due to the reason of good emergence, good spread of plant and more number of stem per plant. While the minimum weight of medium tubers was noted by Toureg and Focus. It is due to poor emergence, low plant spread and small size tubers. It may be due to compact soil which can greatly reduced potato yield, if there are some nutrients, it is used by the weeds [7].

Similarly, other researchers also investigated that marketable yield was significantly varied by variety, location, genotypes and en vironment interaction [19, 31, 32].

\section{Weight of large tubers plot $^{-1}$ (more than 50mm)}

The weight of large tubers plot $^{-1}$ was significantly affected. The maximum weight of large tubers plot $^{-1}$ was recorded in variety Red Sum $(9.4 \mathrm{~kg})$ followed by Red Valentine $(8.4 \mathrm{~kg})$ and Focus $(6.8 \mathrm{~kg})$, while the minimum weight of large tubers plot $^{-1}$ was found in variety Eldorado $(5.4 \mathrm{~kg})$ and Toureg $(5.5 \mathrm{~kg})$. The weight of large tubers plot $^{-1}$ has significant effect. On the other hand Red Sum produced significantly higher weight of large tubers plot $^{-1}$ followed by Red Valentine, whereas the variety Eldorado and Toureg produced minimum weight of large size tubers plot $^{-1}$.

Maximum weight of large tubers plot $^{-1}$ was recorded by Red Sum, Red Valentine and
Focus. It is due to good emergence and good environmental condition of the region, while the minimum weight of large tubers plot $^{-1}$ was recorded by Eldorado and Toureg.

It may be due to compact soil and the nutrients may used by weeds. The varieties which give more number of large tubers plot $^{-1}$ almost give high weight of large tubers plot $^{-1}$. The result reported by [33] are also in agreement with the present study. [34] Observed modifications among the varieties in weight of different tubers and positively correlated between number of tubers and weight of tubers plant ${ }^{-1}$.

\section{Total weight of tubers plot $^{-1}(\mathbf{k g})$}

The total weight of tubers has significant effect. The maximum total weight of tubers plot $^{-1}$ was recorded in variety Red Valentine $(18.8 \mathrm{~kg})$ followed by Red Sum $(18.7 \mathrm{~kg})$, while the minimum total weight of tubers plot $^{-1}$ was recorded by Toureg $(13 \mathrm{~kg})$. The data of total weight of tubers plot $^{-1}$ were recorded and the statistically Red Valentine and Red Sum produced highest total weight of tubers plot $^{-1}$, while the lowest total weight of tubers plot ${ }^{-1}$ were found in Toureg.

Maximum total weight of tubers plot $^{-1}$ was recorded by Red Valentine and Red Sum. It is due to good emergence and good region for potato, and also the varietal characters which produced large number of potato tubers, while the minimum total weight of tubers plot $^{-1}$ was recorded by Toureg. The difference may be due to quality and diseases. [35] Also found a significant difference at the $5 \%$ level in eyes of tuber weight per plant between cultivars was evaluated. [36] Showed that number of tubersplant $^{-1}$, average of tuber weight and plant height were the most closely related to tuber yield.

\section{Moisture (\%)}

The moisture percentage has significant effect. The highest moisture was recorded in variety Eldorado (86.7\%), followed by Elbeida (86.3\%) and Rock (84.7\%), while 
the minimum moisture was recorded in variety Red Sum (73.7\%), followed by Red Valentine $(74.3 \%)$ and Toureg $(77.7 \%)$. On the other hand Eldorado and Elbeida produced significantly higher moisture percentage as compared to other varieties, whereas the variety Red Sum, Red Valentine and Toureg produced minimum moisture percentage.

The moisture percentage has significant effect. The maximum moisture was recorded in variety Eldorado, Elbeida and Rock. It is due to genetic characteristics of a variety containing high moisture content and least shelf life, while the minimum moisture percentage was recorded in variety Red Sum, Red Valentine and Toureg. It is due to character of a variety containing high dry matter percentage, prolongs shelf life and low moisture content. Moisture is very important in fresh potato as well as in the period of storage of any food material. Availability of high moisture is suitable condition for the growth of microorganism and thus decreases the shelf life of potatoes.

\section{Dry matter (\%)}

The dry matter percentage has significant effect. The highest dry matter was recorded in variety Red Sum (26.3\%), followed by Red Valentine (25.7\%), Toureg (22.3\%) and Desiree (20\%), while the minimum dry matter was recorded in variety Eldorado $(13.3 \%)$ and Elbeida (13.7\%).On the other hand variety Red Sum and Red Valentine produced significantly higher dry matter percentage as compared to other varieties, whereas the variety Eldorado and Elbeida produced minimum dry matter percentage.

The maximum dry matter was recorded in variety Red Sum and Red Valentine. It is due to genetic characteristics of a variety containing high dry matter content and high shelf life. The Higher dry matter varieties have high shelf life and good quality, while the minimum dry matter percentage was recorded in variety Eldorado and Elbeida. It is due to character of a variety containing high moisture percentage and low dry matter content. [37] Stated that high rainfall or excessive water will cause to low dry matter content in potato tubers. The dry matter content of tubers varied considerably between cultivars and is a strongly heritable based character [38]. The dry matter amount highly has been described to be really related with a lower sugar concentration during storage $[39,40]$. In other research dry matter content is influenced by both of the environment and genotypes [41].

\section{Total yield (tons/ha)}

The yield (tons/ha) was significantly affected. The highest yield (tons/ha) was recorded in variety Red Valentine (25) and Red Sum (24.9), while the minimum yield (tons/ha) was recorded in variety Toureg (17.3) and Desiree (17.4). On the other hand Red Valentine and Red Sum produced significantly higher yield (tones/ha) as compared to other varieties, whereas the variety Toureg and Desiree produced minimum yield (tons/ha).

The maximum yield (tones/ha) was recorded in Red Valentine and Red Sum. It is due to good emergence percentage, more number of stems per plant. When more number of stems, more will be number of tubers, so when more number of tubers the yield will be greater, while the minimum yield (tons/ha) was recorded by Toureg and Desiree. It may be due to poor plant spread and poor sized tubers [2].

[18] Stated that the rapid plant emergence and better plant growth result in higher tuber yield. [42] Added that the higher number of tubers per plant may due to the overall effect of vigorous growth of all the plants while [43] reported that longer growing periods affects the yield and also enhances the number of tubers per plant and tuber size (Table 1). 
Ullah et al.

Table 1. Effect of potato varieties on the selected parameters

\begin{tabular}{|c|c|c|c|c|c|c|c|c|c|c|c|c|c|c|}
\hline \multirow[b]{2}{*}{ Varieties } & \multicolumn{14}{|c|}{ Means } \\
\hline & Sprouting \% & $\begin{array}{c}\text { No of } \\
\text { stem } \\
\text { plant }^{-1}\end{array}$ & $\begin{array}{c}\text { Disease } \\
\%\end{array}$ & $\begin{array}{c}\text { No of } \\
\text { small } \\
\text { tubers } \\
\text { plot }^{-1}\end{array}$ & $\begin{array}{c}\text { No of } \\
\text { medium } \\
\text { tubers } \\
\text { plot }^{-1}\end{array}$ & $\begin{array}{l}\text { No of } \\
\text { large } \\
\text { tubers } \\
\text { plot }^{-1}\end{array}$ & $\begin{array}{l}\text { Total } \\
\text { No. of } \\
\text { tubers } \\
\text { plot }^{-1}\end{array}$ & $\begin{array}{c}\text { Wt. of } \\
\text { small } \\
\text { tubers } \\
\text { plot }^{-1}\end{array}$ & $\begin{array}{c}\text { Wt. of } \\
\text { medium } \\
\text { tubers } \\
\text { plot }^{-1}\end{array}$ & $\begin{array}{l}\text { Wt. of } \\
\text { large } \\
\text { tubers } \\
\text { plot }^{-1}\end{array}$ & $\begin{array}{c}\text { Total } \\
\text { wt. of } \\
\text { tubers } \\
\text { plot }^{-1}\end{array}$ & $\begin{array}{c}\text { Moisture } \\
\%\end{array}$ & $\begin{array}{c}\text { Dry } \\
\text { Matter } \\
\%\end{array}$ & $\begin{array}{c}\text { Yield } \\
\text { (ton/ha) }\end{array}$ \\
\hline Rock & $86.7 \mathrm{abc}$ & $5 \mathrm{ab}$ & $21.7 \mathrm{bc}$ & $104 \mathrm{c}$ & $25 \mathrm{~cd}$ & $15 \mathrm{bc}$ & $144 \mathrm{c}$ & $3 \mathrm{~cd}$ & $4.9 \mathrm{c}$ & $6.4 \mathrm{bc}$ & $14.3 \mathrm{~b}$ & $84.7 \mathrm{ab}$ & $15.3 \mathrm{bc}$ & $19 \mathrm{~b}$ \\
\hline Red Sum & $97.5 \mathrm{a}$ & $5.3 \mathrm{a}$ & $5.0 \mathrm{~d}$ & $57 d$ & $35 \mathrm{ab}$ & $27 \mathrm{a}$ & $120 \mathrm{~d}$ & $2.3 \mathrm{~d}$ & $7 \mathrm{ab}$ & $9.4 \mathrm{a}$ & $18.7 \mathrm{a}$ & $73.7 \mathrm{c}$ & $26.3 \mathrm{a}$ & $24.9 \mathrm{a}$ \\
\hline Aurea & $92.5 \mathrm{ab}$ & 4. cd & $38.3 \mathrm{a}$ & $109 \mathrm{bc}$ & $27 \mathrm{~cd}$ & $17 \mathrm{~b}$ & $152 \mathrm{bc}$ & $3 \mathrm{bcd}$ & $4.5 \mathrm{c}$ & $6.6 \mathrm{bc}$ & $14.2 \mathrm{~b}$ & $82.3 \mathrm{ab}$ & $17.7 \mathrm{bc}$ & $18.9 \mathrm{~b}$ \\
\hline Nazca & $90.8 \mathrm{ab}$ & $4.6 a b c$ & $14.2 \mathrm{~cd}$ & $116 \mathrm{~b}$ & 31 abcd & $15 \mathrm{bc}$ & $162 \mathrm{ab}$ & $3.3 a b c$ & $5.5 \mathrm{bc}$ & $5.8 \mathrm{bc}$ & $14.6 \mathrm{~b}$ & $84.3 \mathrm{ab}$ & $15.7 \mathrm{bc}$ & $19.4 \mathrm{~b}$ \\
\hline Focus & $71.7 \mathrm{~cd}$ & $5 \mathrm{ab}$ & $42.5 \mathrm{a}$ & $104 \mathrm{c}$ & $29 \mathrm{bcd}$ & $18 \mathrm{~b}$ & $151 \mathrm{bc}$ & $2.8 \mathrm{~cd}$ & $4.1 \mathrm{c}$ & $6.8 \mathrm{abc}$ & $13.7 \mathrm{~b}$ & $81.3 \mathrm{abc}$ & $18.7 \mathrm{abc}$ & $18.3 b$ \\
\hline Eldorado & $95.8 \mathrm{ab}$ & $4.6 \mathrm{abc}$ & $33.3 \mathrm{ab}$ & $131 \mathrm{a}$ & $26 \mathrm{~cd}$ & $14 \mathrm{bc}$ & $170 \mathrm{a}$ & $4 a b$ & $4.2 \mathrm{c}$ & $5.4 \mathrm{c}$ & $13.6 \mathrm{~b}$ & $86.7 \mathrm{a}$ & $13.3 \mathrm{c}$ & $18.1 \mathrm{~b}$ \\
\hline Desiree & $80.0 \mathrm{bcd}$ & $3.6 \mathrm{~d}$ & $16.7 \mathrm{~cd}$ & $110 \mathrm{bc}$ & $32 a b c$ & $15 \mathrm{bc}$ & $157 a b c$ & $2.9 \mathrm{~cd}$ & $4.5 \mathrm{c}$ & $5.7 \mathrm{c}$ & $13.1 \mathrm{~b}$ & $80.0 \mathrm{abc}$ & $20 a b c$ & $17.4 \mathrm{~b}$ \\
\hline Elbeida & $89.2 \mathrm{ab}$ & $3.6 \mathrm{~d}$ & $33.3 \mathrm{ab}$ & $105 \mathrm{c}$ & $32 a b c$ & $16 \mathrm{bc}$ & $153 \mathrm{bc}$ & $4.1 \mathrm{a}$ & $4.3 \mathrm{c}$ & $6.0 \mathrm{bc}$ & $14.4 \mathrm{~b}$ & $86.3 \mathrm{a}$ & $13.7 \mathrm{c}$ & $19.2 b$ \\
\hline Red Valentine & $98.3 \mathrm{a}$ & $4.6 \mathrm{abc}$ & $6.7 \mathrm{~d}$ & $64 \mathrm{~d}$ & $39 \mathrm{a}$ & $25 \mathrm{a}$ & $128 \mathrm{~d}$ & $2.2 \mathrm{~d}$ & $8.2 \mathrm{a}$ & $8.4 \mathrm{ab}$ & $18.8 \mathrm{a}$ & $74.3 \mathrm{c}$ & $25.7 \mathrm{a}$ & $25.0 \mathrm{a}$ \\
\hline Toureg & $66.7 \mathrm{~d}$ & $4.3 \mathrm{bcd}$ & $21.7 \mathrm{bc}$ & $125 \mathrm{a}$ & $23 \mathrm{~d}$ & $11 \mathrm{c}$ & $160 a b c$ & $3.6 \mathrm{abc}$ & $4 \mathrm{c}$ & $5.5 \mathrm{c}$ & $13 \mathrm{~b}$ & $77.7 \mathrm{bc}$ & $22.3 \mathrm{ab}$ & $17.3 \mathrm{~b}$ \\
\hline $\operatorname{LSD}(1 \%)$ & 17.108 & 0.9959 & 11.983 & 9.3124 & 8.5352 & 5.545 & 15.914 & 1.0103 & 2.0181 & 2.736 & 2.836 & 7.7303 & 7.7303 & 3.802 \\
\hline
\end{tabular}

Mean values followed by different letters are significantly different while mean showing similar letters are not different significantly from one another 


\section{Conclusion and recommendations}

Maximum sprouting percentage was recorded in Red Valentine and Red Sum, highest number of stem plant ${ }^{-1}$ was noted in Red Sum, lowest number of small tubers plot $^{-1}$ was in variety Red Sum and Red Valentine, highest number of medium and large tubers plot ${ }^{-1}$ was found in variety Red Sum and also in Red Valentine, lowest weight of small tubers plot $^{-1}$ in variety Red Sum and Red Valentine. The highest weight of large tubers plot $^{-1}$ was also noted in Red Sum and Red Valentine. The variety Red Sum and Red Valentine was least disease affected, low number of small tubers plot $^{-1}$ and highest weight of total tubers plot ${ }^{-1}$. The highest dry matter percentage and lowest moisture percentage was also recorded in variety Red Sum and Red Valentine. The highest yield (tons/ha) was also found in variety Red Valentine and Red Sum. The both varieties Red Sum and Red Valentine give superior result and recommended for the farmers and for general cultivation in the climatic conditions of Abbottabad Hazara.

\section{Authors' contributions}

Conceived and designed the experiments:

R Ullah, G Nabi \& I Khan, Performed the experiments: R Ullah, BA Khan, Analyzed the data: R Ullah, JA Jan \& A Khan, Contributed materials/ analysis/ tools: R Ullah, Wrote the paper: R Ullah \& N Khan.

\section{References}

1. Malik NJ (1995). Potatoes in Pakistan A handbook.Pak-Swiss Potato Dev. Proj. Pakistan Agric. Res. Council, P.O. Box 1031, Islamabad, Pakistan.

2. Muhammad $\mathrm{N}$ and Muhammad $\mathrm{S}$ (2003). Response of earthing up at different stages of growth on the yield and performance of different potato varieties in the plains of Peshawar. M.Sc. Thesis, submitted by Niaz Muhammad and Sher Muhammad to the department of Horticulture, The
University of Agriculture, Peshawar, pp 36.

3. Fruit, vegetables and condiments statistics of Pakistan (2015-16).

4. Agriculture Statistics of Pakistan (20172018) .Ministry of Food and Agriculture, Govt. of Pakistan, Islamabad, Pakistan.

5. Gould WA \& Plimpton S (1985). Quality evaluation of potato cultivars for processing. Agricultural Experiment Stations of Illinois, Indiana, and the US Department of Agriculture cooperating.

6. Nizamuddin, Qamar M, Mirza B, Shakirullah, Asghar M, Ahmad S, Din M, Hussain I \& Baig D (2010). Yield performance of true potato seeds (TPS) hybrids under climatic conditions of Northern Areas. Sarhad J Agric 26(2): 241-244.

7. Behjati S, Choukan R, Hassanabadi H \& Delkhosh B (2013). The evaluation of yield and effective characteristics on yield of promising Potato clones. Annals of Bio Res 4(7): 81-84.

8. Rab A, Nabi G, Amin NU, Haq I, Sajid M, Nawab K and Ara N (2013). Influence of sowing time and potato propagules on the yield and tuber quality. Pak J Bot 45(6).

9. Steel RGD \& Torrie JH (1984). Principles and procedures of statistics. Mc Graw Hill Book Co. New York, USA.107-109.

10. Wurr DCE, Fellows JR \& Allen EJ (1993). An approach to determining optimum tuber planting densities in early potato varieties. J Agri Sci (Cambridge) 120: 63-70.

11. Ifenkwe OP \& Allen EJ (1978). Effects of tuber size on dry-matter content of tubers during growth of two main crop potato varieties. National Root Crop Research Institute, Irish Potato Research, Jos, Nigeria 21(2): 105-112. 
12. Dehdar B (2005). Evaluation of quantitative and qualitative traits of falling cultivation of potato in Moganregion. Fourth Congress of Horticultural Science, pp 16.

13. Laie GR \& Laie (2009). Determine the best planting date and depth on the seed tubers of potato cultivars Agria and Draga in North Khorasan condition. $J$ of Crop Sci 3.

14. Rashid MH, Kabir MH \& Sikka LC (1990). True potato seed (TPS) in Bangladesh.000. In: Proc. True Potato Seed (TPS) in South and South East Asia. MD Upadhya. (ed.), Delhi, India, 4-8 Jan. 1989. 1: 1-9.

15. Bohl WH, Nolte P, Kleinkopf GE \& Thornton MK (1995) Potato Seed Management, Seed size and age. Cooperative Extension Bulletin. CIS 1031. College of agriculture, Univ. of Idaho, USA.

16. Simongo DK, Gonzales IC \& Sagalla EJD (2011). Evaluation of potato entries for yield and fry quality grown in different elevations of Benguet, Philippines. J of Inter Soc Southeast Asian Agri Sci 17(2). 117-127.

17. Kadian MS, Thakur KC \& Upadhya MD (1996). Production and utilization of autumn and spring TPS seedling tubers. J Indian Potato Assoc 23(1): 6268.

18. Patel CK, Patel PT \& Chaudhari SM (2008). Effect of physiological age and seed size on seed production of potato in North Gujarat. 35: 85-87.

19. Kumar S, Khade HD, Dhokane VS, Bethere AG \& Sharma A (2007). Irradiation in Combination With Higher Storage Temperatures Maintains ChipMaking Quality of Potato. J Food Sci 72.

20. Sadiq M, Tariq AH, Iqbal M, Asghar KA (1995). Evaluation of red skinned exotic indigenous potato strains at vegetable Res. Faisalabad. 32-8. Research and Development of Potato Production in Pakistan.

21. Bussan AJ, Mitchell PD, Copas ME \& Drilias MJ (2007). Evaluation of the effect of density on potato yield and tuber size distribution. Crop Sci 47: 2462-2472.

22. Kumar D \& Ezekiel R (2006). Effect of physiological and biochemical attributes of potato cultivars KufriLauvkar and Atlantic on their chipping quality. Am Potato J 33(1-2): 50-55.

23. Bremner, T \& Taha MA (1966). Studies in potato agronomy: The effects of variety, seed size and spacing on growth, development and yield. Agri Sci J (London) 66: 241-252.

24. Madalageri, MB (1999). True potato seed (TPS) technology for rainfed vertisols. V. Economics of crop production from TPS transplanting method vis-a-vis seed tuber planting method. Advances in Plant Sci Res India 10: 29-32.

25. Sikka LC, Bhagari AS, Ssebuliba JM \& Kanzikwera R (1994). Potato production from true potato seed. Acta Horticulturae. 380: 484-489.

26. Wurr DCE, Fellows JR, Suthrland RA, \& Allen EJ (1990). J of Agri Sci 114: 11-18.

27. Robert KP, McRae KB, Midmore DJ \& Deng R (1990). Reduction in potato growth at high tmerarture: Role of photosynthesis and dark respiration. Am Potato J 67 (6): 357-369.

28. Subarta M, Upadhya MO (1997). Potato production in western Bengal. Environ Ecol 15: 646-9.

29. Muthuraj R, Ravichandran G, Krishna KS \& Singh S (2005). Effect of planting date on seed size tuber yield of potato in Nilgiris. Potato J 32(3-4): 239.

30. Azad S, Nehra BK, Khurana SC \& Singh N (1997). Influence of plant 
density and geometry on growth and yield in seed crop of potato. Indian Potato Assoc 24(1-2): 17-23.

31. Elfinesh F (2008). Processing quality of improved Potato (SolanumtuberosumL.) varieties as influenced by growing environment, genotype and blanching. An M. Sc. Thesis submitted to the school of graduate studies of Haramaya University.

32. Pandey SK, Sing SV, Kumar $\mathrm{P} \&$ Manive P (2004). Sustaining potato chipping Industry from western and central Uttar Pardesh: Adoption of suitable varieties. Potato J 31(3-4): 119127.

33. Habtamu G, Wahassu M \& Beneberu S (2016). Evaluation of Potato (Solanumtuberosum L.) Varieties for Yield and Yield Components in Eastern Ethiopia. Greener $J$ of Plant Breeding and Crop Sci 4(2): 014-026.

34. Hanan A, Ali $\mathrm{N} \&$ Inayatullah $\mathrm{H}$ (1998). Cooperative performance of the French cultivars in Peshawar valley. Sarhad J Agri 3: 460-70.

35. Taghdiri B \& Gholami M (2006). Effect of plant density on potato (Agria and Marfona) tubers in the Hamadan region. Iranian J of Agri Sci 1022-1017.

36. Estevez A, Arzuga J \& Correa S (1982). Study of characters related to yield in potato. Cultivars Tropicales. 4(3): 549558

37. Kellock T (1995). Potatoes: factors affecting dry matter. Department of Primary Industries.

38. Toolangi TK (1995). Potatoes: factors affecting dry matter. Agriculture notes, April. State of Victoria, Department of Primary Industries, USA.

39. Watada A \& Kunkel R (1955). The variation in reducing sugar content in different varieties of potatoes. American Potato J 32:132-140.

40. Iritani WM \& Weller LD (1976). Relationship of specific gravity to sugar accumulation in stored Norgold and Russet Burbank potatoes. American Potato J 53:57-65.

41. Tai GCC \& Coleman W (1999). Genotype environment interaction of potato chip color. Can J Plant Sci 79: 433-438.

42. Wang R, Lihua L, Liu H \& Wang RG (1995). Present state of research on potato germplasm resources in China. Crop Genetic Res 3: 20-2.

43. Mehdi, M, Saleem T, Rai HK, Mir MS \& Rai G (2008). Effect of nitrogen and FYM interaction on yield and yield traits of potato genotypes under Ladakh condition. Potato J 35(3-4): 126-129. 